\title{
Notes on the Biology of some Lamellibranchs in the Clyde Area.
}

\author{
By \\ A. C. Stephen, B.Sc., F.R.S.E., \\ Royal Scottish Museum, Edinburgh, and from the \\ Marine Station, Millport.
}

With 3 Figures in the Text.

\section{Contents.}

1. Introduction

2. Tellina tenuis

3. Tellina fabula

4. Abra alba

5. Cardium edule.

6. Cardium edule .

Loch Fyne

7. Renewal of a Lamellibranch Population

8. Summary

9. Literature cited

10. Appendix

\section{INTRODUCTION.}

For the past few years certain common Scottish intertidal Lamellibranchs have been studied, chiefly with a view to tracing the rate of growth and fluctuations of the various year-groups. The investigations in the Clyde Sea Area have now been extended to include certain species living below L.W.M., two of which are discussed in the present paper. The species dealt with are Cardium edule, Tellina tenuis, Tellina fabula, and Abra alba.

The measurement of length used in the various tables, both of the shell and of the annual ring, is that of the greatest antero-posterior diameter, taken to the nearest mm. above, e.g. $4 \cdot 1$ to $5 \cdot 0 \mathrm{~mm}$. being given as $5 \mathrm{~mm}$. The lengths of the shells were measured on a measuring-board and those of the rings were taken by means of jointed dividers.

For sampling below L.W.M. the Robertson Bucket Dredge was used.

The dredged material was usually put through a 2-mm. sieve, with a check sample through the 1-mm. sieve.

I am indebted to Mr. R. Elmhirst, the Superintendent of the Marine Station at Millport, for his assistance in collecting most of the material on which this paper is based. 


\section{Tellina tenuis.}

The rate of growth of this species, at and above L.W.M. in Kames Bay, has been studied for several years, but the rate of growth below L.W.M. was not satisfactorily worked out owing to scanty material.

The species occurs plentifully in Kames Bay in the intertidal region and

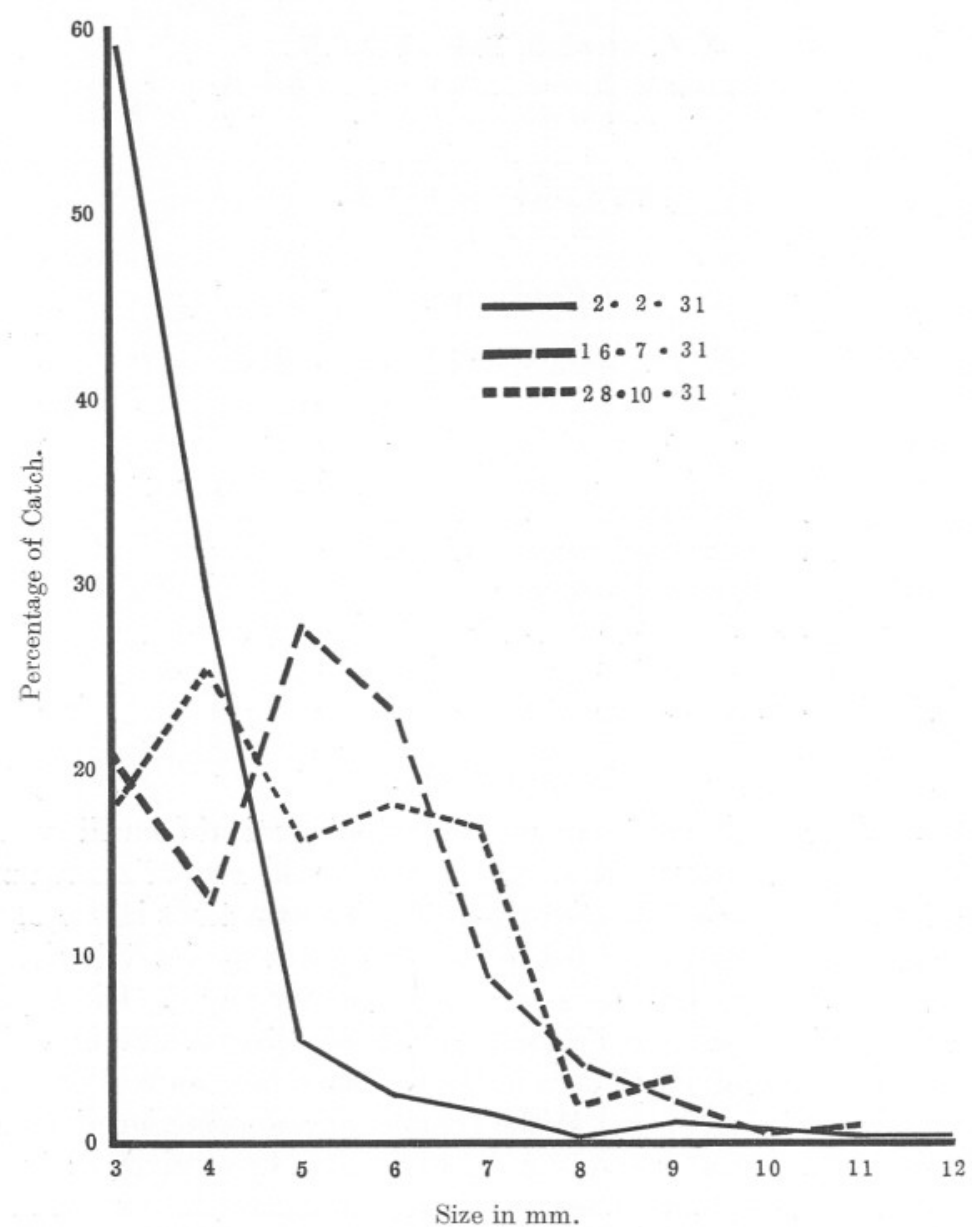

Fig. 1.-Showing the size-frequency curves for the collections of Tellina tenuis taken in $1 \frac{1}{2} \mathrm{fm}$. in Kames Bay, Millport, during 1931.

just below L.W.M., but does not extend seawards beyond about $2 \frac{1}{2}$ fathoms. When investigations were begun in 1926 a few dredgings were taken, but the material was too scanty to allow of more than the general conclusions that (1) the rate of growth in shallow water was less than at 
L.W.M. and (2) spat did not survive in quantity for very long, leaving the ground comparatively sparsely populated.

Following the heavy spat-fall in the late summer of 1930 it was felt that this would prove a suitable opportunity for completing the study of the rate of growth of the species in Kames Bay over the whole of its vertical range. Investigations were confined to one station in Kames Bay (Appendix, p. 68) where both T. tenuis and T. fabula were abundant, and collections were taken three times during the year with the Robertson Bucket Dredge, a minimum of twenty hauls being taken at each visit. As already mentioned, there was abundant spat in 1930 and this is reflected in the size-frequency curve for February, 1931 (Table 3; Fig. 1), where nearly $90 \%$ of the population was under $5 \mathrm{~mm}$. On this curve there was only one well-marked group, with the mode at $3 \mathrm{~mm}$. On the curve for July there were two distinct modes, one at $3 \mathrm{~mm}$. representing the new 1931 spat and the other, representing the older 1930 spat, at $5 \mathrm{~mm}$. On the curve for October there were again two modes at $4 \mathrm{~mm}$. and $6 \mathrm{~mm}$. respectively, but in this case the number of specimens is so small that too much reliance cannot be placed on the figures.

The results of the dredgings taken in the autumn of 1926 are interesting and show a close parallel to those of February, 1931. Then, also, there was only one well-marked group on the ground, with a mode at $3 \mathrm{~mm}$. In the middle of April, 1927, the mode was still the same, but by the middle of August it had moved to $6 \mathrm{~mm}$. and the new spat gave a mode at $3 \mathrm{~mm}$. In the autumn of 1927 there were two well-marked groups on the ground: the 1927 spat, mode at $3 \mathrm{~mm}$., and the 1926 spat, mode at $6 \mathrm{~mm}$.

The collections taken during 1928 and 1929 contained so few specimens: that they need not be considered, with the exception of a collection taken in March, 1928. The size-frequency curve for that collection was the same as that of the previous autumn, showing that below L.W.M., as above, there had been no growth during the winter months.

The modes for the size-frequency curves for collections with a reasonably large number of specimens may thus be tabulated :-

TABLE 1.

6.10 .26

13.4.27

13.8 .27

8.10 .27

23.3.28

2.2 .31

16.7 .31

28.10 .31

\section{6 spat.}

$3 \mathrm{~mm}$.

$3 \mathrm{~mm}$.

$6 \mathrm{~mm}$.

$6 \mathrm{~mm}$.

$6 \mathrm{~mm}$.

1930 spat.

$3 \mathrm{~mm}$.

$5 \mathrm{~mm}$.

$6 \mathrm{~mm}$.
1927 spat.

$3 \mathrm{~mm}$.

$3 \mathrm{~mm}$.

$3 \mathrm{~mm}$.

1931 spat.

$3 \mathrm{~mm}$.

$4 \mathrm{~mm}$. 
Thus in both 1926 and 1930, following heavy spat-fall, the year-groups could be followed for a time. The 1926 spat could be traced until the spring of 1928 but seems to have died out during that year. The 1930 spat was still present as a distinct group in the autumn of 1931 but was already thinning out.

In the intervening years, with seemingly less spat, the species was comparatively scarce on the sublittoral ground, and with the few specimens taken no year-groups could be traced.

The falling-off in abundance is important and shows that the species is now best adapted for life in the intertidal area. In 1926 and 1927 so few specimens were taken that the figures are unreliable, but the 1931 collections offer suitable material. As is shown in Table 2, both T. tenuis and $T$. fabula decreased in abundance, especially the former.

\section{TABLE 2.}

Table Showing the Actual Numbers of T. tenuis and T. fabula in 20 haUls in Kames BaY DURING 1931.

$\begin{array}{lccc} & 2.2 .31 . & 16.7 .31 . & 28.10 .31 . \\ T . \text { tenuis } & 1566 & 301 & 155 \\ T . \text { fabula } & 1363 & 755 & 546\end{array}$

The results of the investigations, Stephen (3), on T. tenuis, both above and below L.W.M. in Kames Bay, may be thus summarised :-

The species breeds in summer. Growth is greatest in the upper parts of the beach and least below L.W.M. In 1926 and 1930 spat was unusually abundant both above and below L.W.M. Above L.W.M. the 1926 spat dominated the ground until the summer of 1930, when it largely died out and was replaced by the 1930 spat, which remains at present the dominant year-group. Below L.W.M. in both 1926 and 1930 the results were very similar in that the spat grew slowly and died off rapidly.

The size of the species at the end of each year of life in Kames Bay, judged from the modes of the various size-frequency curves, may be taken to be as follows :-

\section{End of first year of life \\ ", second year of life \\ ", third year of life \\ , fourth year of life}

\begin{tabular}{|c|c|c|}
\hline \multicolumn{3}{|c|}{ Position on the Beach. } \\
\hline $3 \mathrm{~mm}$. & $3 \mathrm{~mm}$. & $3 \mathrm{~mm}$. \\
\hline $6 \mathrm{~mm}$. & $7 \mathrm{~mm}$. & $9 \mathrm{~mm}$. \\
\hline . & $9 \mathrm{~mm}$. & $12 \mathrm{~mm}$. \\
\hline . & $11 \mathrm{~mm}$. & . \\
\hline
\end{tabular}




\section{TABLE 3.}

Table Showing the Percentage of the Total Catch at each mm.Size in the Collections of $T$. tenuis from Stn. 6, Kames Bay, 1931.

$\begin{array}{lcccccccccccccc}\text { Date. } & 3 & 4 & 5 & 6 & 7 & 8 & 9 & 10 & 11 & 12 & 13 & 14 & 15 & \begin{array}{r}\text { Total } \\ \text { speci- } \\ \text { mens. }\end{array} \\ 2.2 .31 & 58 \cdot 8 & 29 \cdot 7 & 5 \cdot 5 & 2 \cdot 4 & 1 \cdot 5 & 0 \cdot 4 & 0 \cdot 7 & 0 \cdot 5 & 0 \cdot 2 & 0 \cdot 2 & 0 \cdot 1 & . & 0 \cdot 1 & 1566 \\ 16.7 .31 & 21 \cdot 0 & 12 \cdot 7 & 27 \cdot 6 & 23 \cdot 2 & 8 \cdot 7 & 4 \cdot 0 & 2 \cdot 0 & 0 \cdot 3 & 0 \cdot 6 & . & . & . & . & 301 \\ 28.10 .31 & 18 \cdot 7 & 25 \cdot 1 & 16 \cdot 1 & 18 \cdot 1 & 16 \cdot 8 & 1 \cdot 9 & 3 \cdot 2 & . & . & . & . & . & . & 155\end{array}$

\section{Tellina fabula.}

This species is distributed over the shallow, sandy ground in Kames Bay from about L.W.M. springs to 10 fathoms. Its area of distribution overlaps that of T. tenuis in the region just below L.W.M. Prior to 1931 several attempts had been made to determine the rate of growth, but these were unsuccessful, chiefly because insufficient material was collected. The earlier work, however, was not entirely wasted since the curves contain confirmatory evidence on several points.

\section{Rate of Growth (Table 4; Fig. 2).}

Material was collected from one station in Kames Bay, Millport, on clean sand at a depth of $1 \frac{1}{2}$ fathom at low tide in February, June, and October, 1931.

On the size-frequency curve for February there is one well-marked mode at $4 \mathrm{~mm}$., representing the 1930 spat, and there is a hint of a mode between $9 \mathrm{~mm}$. and $11 \mathrm{~mm}$., probably the 1928 spat. It may be assumed that in this, as in other species, there is no growth during the winter months and that the mode at $4 \mathrm{~mm}$. represents the modal size of the 1930 spat at the end of the previous autumn.

On the curve for July there are two well-marked modes, one at $4 \mathrm{~mm}$., representing the new 1931 spat, and another at $7 \mathrm{~mm}$., representing the 1930 spat. The species, therefore, appears to breed in early summer, probably about the same time as $T$. tenuis.

On the October curve there are again two well-marked modes, one at $5 \mathrm{~mm}$., representing the 1931 spat, the other at $8 \mathrm{~mm}$., representing the 1930 spat.

From the figures for 1931 the rate of growth of the species in Kames Bay may be taken as follows :-

$\begin{array}{cc}\text { At end of First } & \text { At end of Second } \\ \text { Autumn. } & \text { Autumn. } \\ 4-5 \mathrm{~mm} . & 8 \mathrm{~mm} .\end{array}$

At end of Third Autumn. probably $10 \mathrm{~mm}$. 
A. C. STEPHEN.

In the autumn of 1930 the spat of that year had the mode at $4 \mathrm{~mm}$., while in the autumn of 1931 the mode was at $5 \mathrm{~mm}$. The conditions of growth would therefore seem to have been more favourable in 1931, although the result may have been due to less competition for food, since the 1930 spat was very much more numerous than that of 1931.

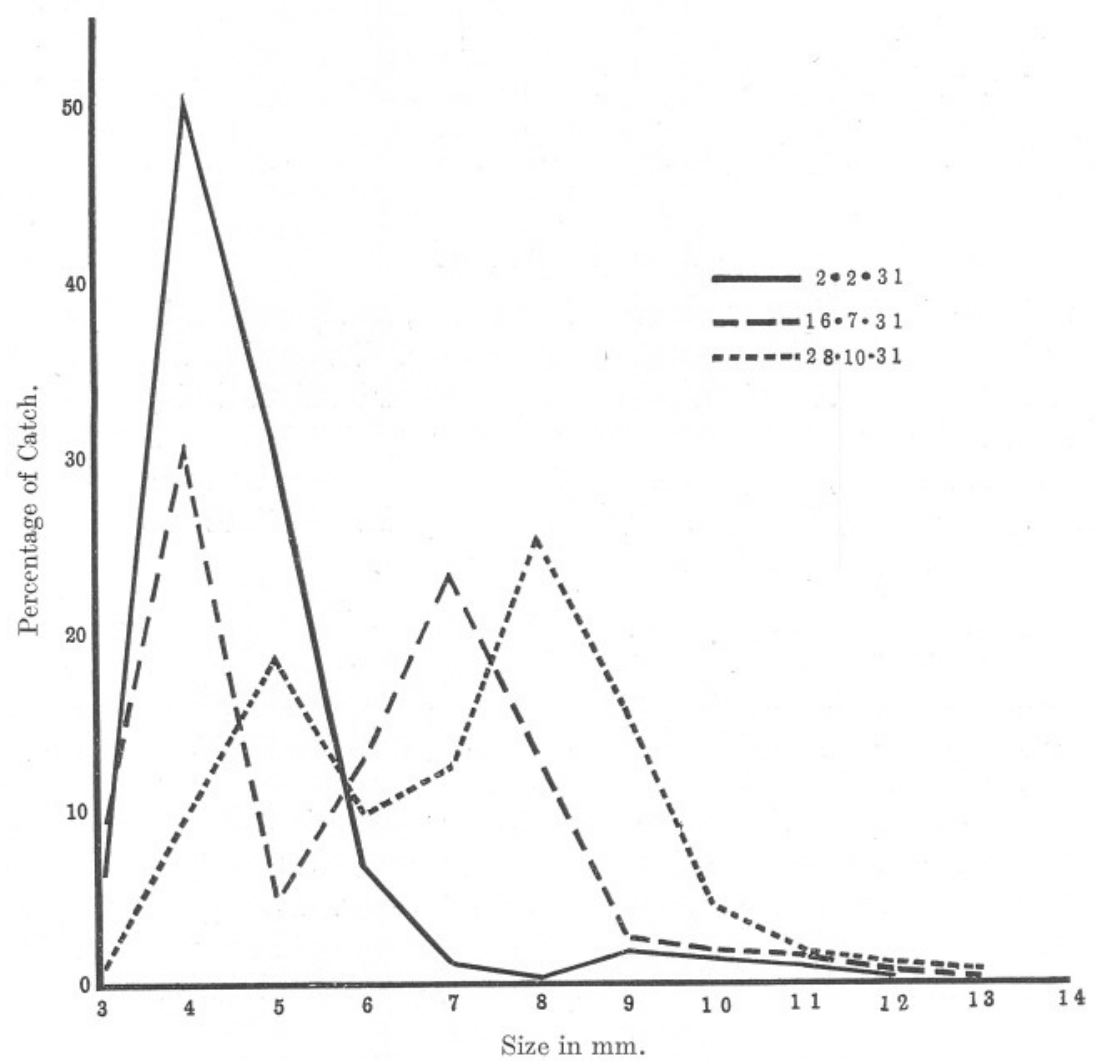

FIg. 2.- Showing the size-frequency curves for the collections of Tellina fabula taken in $1 \frac{1}{2} \mathrm{fm}$. in Kames Bay, Millport, during 1931 .

The figures for the previous collections of T. fabula in Kames Bay confirm those given above and show that they represent the usual conditions in the bay. For example, during 1928 the modes of the 1927 spat were as follows :-
23.3 .28
25.4 .28
$5 \mathrm{~mm}$.
6.6 .28
$5 \mathrm{~mm}$.
29.9 .28
$6 \mathrm{~mm}$.
7-8 $\mathrm{mm}$.

The autumn mode for the 1928 spat was at $4 \mathrm{~mm}$. 
T. fabula would seem to die out about the end of its third year of life, probably like T. tenuis, after the summer spatting. Some few specimens may be older, but there is no evidence on the curves of the survival of more than a very few individuals after that age.

The autumn of both 1926 and 1930 was a period of exceptional survival of $T$. tenuis spat. Full figures are not available for $T$. fabula over the whole period, but a comparison of the figures for 1926, 1928, and 1930 (Table 4), would suggest that these years were marked also by an abundant survival of the spat of this species in Kames Bay.

\section{TABLE 4.}

\section{Table Showing the Size-Frequencies of T. FabUla in Kames Bay.}

A, during 1926 and 1928 when only a few dredgings were taken at one time. B, during 1931 when a minimum of 20 hauls was taken at each time.

\begin{tabular}{|c|c|c|c|c|c|c|c|c|c|c|c|c|c|}
\hline & 3 & 4 & 5 & 6 & 7 & A. & 9 & 10 & 11 & 12 & 13 & 14 & $\begin{array}{l}\text { No. of } \\
\text { speci- } \\
\text { mens. }\end{array}$ \\
\hline 6.10 .26 & $24 \cdot 7$ & 52.5 & $13 \cdot 7$ & $2 \cdot 0$ & $2 \cdot 0$ & . & $2 \cdot 0$ & . & $2 \cdot 0$ & . & . & 1.0 & 101 \\
\hline 23.3 .28 & $8 \cdot 3$ & $18 \cdot 2$ & $31 \cdot 4$ & $19 \cdot 0$ & $7 \cdot 5$ & $7 \cdot 5$ & $2 \cdot 5$ & 1.7 & $2 \cdot 5$ & $0 \cdot 8$ & $0 \cdot 8$ & . & 121 \\
\hline 25.4 .28 & $10 \cdot 9$ & $21 \cdot 7$ & $22 \cdot 2$ & $20 \cdot 7$ & $8 \cdot 3$ & $5 \cdot 2$ & $3 \cdot 1$ & $3 \cdot 1$ & $3 \cdot 1$ & 1.0 & 0.5 & . & 193 \\
\hline 6.6 .28 & $2 \cdot 6$ & $6 \cdot 6$ & $26 \cdot 0$ & $26 \cdot 9$ & $14 \cdot 3$ & $10 \cdot 9$ & $7 \cdot 4$ & $3 \cdot 0$ & 0.9 & $1 \cdot 3$ & . & . & 230 \\
\hline 29.9 .28 & $11 \cdot 5$ & $15 \cdot 4$ & $7 \cdot 7$ & $11 \cdot 5$ & $23 \cdot 1$ & $19 \cdot 2$ & $11 \cdot 5$ & . & . & . & . & . & 26 \\
\hline & & & & & & B. & & & & & & & \\
\hline 2.2 .31 & $6 \cdot 1$ & $50 \cdot 7$ & $31 \cdot 1$ & $6 \cdot 6$ & $1 \cdot 2$ & 0.3 & $1 \cdot 6$ & $1 \cdot 2$ & 0.9 & $0 \cdot 2$ & . & . & 1363 \\
\hline 16.7.31 & $8 \cdot 7$ & $30 \cdot 8$ & $5 \cdot 0$ & $13 \cdot 0$ & $23 \cdot 2$ & $13 \cdot 0$ & $2 \cdot 8$ & $1 \cdot 4$ & $1 \cdot 4$ & 0.5 & $0 \cdot 1$ & . & 755 \\
\hline 28.10 .31 & 0.9 & 9.9 & $18 \cdot 9$ & $9 \cdot 9$ & $12 \cdot 4$ & $25 \cdot 2$ & $15 \cdot 7$ & $4 \cdot 2$ & 1.5 & $1 \cdot 1$ & $0 \cdot 2$ & . & 546 \\
\hline
\end{tabular}

\section{Abra alba.}

The rate of growth of this species was studied in Loch Striven, chiefly at Station 11 (Appendix, p. 68), samples being taken in spring, summer and autumn. These collections were supplemented by two others taken at Stations 10 and 11 (Appendix, p. 68) in Loch Striven in September, 1930, by Mr. Moore, which he kindly handed to me for examination.

Abra alba usually has well-marked rings on the shell, which may safely be taken as annual or winter rings (Ford, 2, p. 540). Before the age of the shells can be read it must first be proved whether the first wellmarked ring is the first or second winter wing. In the Clyde area in C. edule, for example, the first winter ring is very faint and the first conspicuous ring is really the second winter ring. In $A$. alba, however, the first distinct ring is the first winter ring, the evidence for which statement is as follows, Table 5 . 


\section{TABLE 5.}

Table Showing the Numbers, Average Size, and Range of all Specimens without a Winter Ring at each Date of Collection in Loch Striven during 1931.

\begin{tabular}{|c|c|c|c|}
\hline $\begin{array}{l}\text { Date of } \\
\text { collection. }\end{array}$ & $\begin{array}{l}\text { Number of } \\
\text { specimens. }\end{array}$ & $\begin{array}{l}\text { Range } \\
\text { in size. }\end{array}$ & $\begin{array}{l}\text { Average } \\
\text { size. }\end{array}$ \\
\hline 13.2 .31 & 1 & $10 \mathrm{~mm}$ & $10 \mathrm{~mm}$. \\
\hline 19.6.31 & . & . & . \\
\hline 20.8 .31 & 64 & $3-11 \mathrm{~mm}$. & $5.6 \mathrm{~mm}$ \\
\hline 29.10 .31 & 42 & $6-11 \mathrm{~mm}$. & $8.1 \mathrm{~mm}$ \\
\hline
\end{tabular}

In the February collection there was only one specimen, the smallest of the collection, which had no winter ring within the margin of the shell, the winter ring at $10 \mathrm{~mm}$. being in the course of formation. In the June collection all specimens had rings and those with one ring ranged from 9 to $13 \mathrm{~mm}$. In the August collection there were numerous small specimens without rings, ranging from 3 to $11 \mathrm{~mm}$. and with an average size of $5.6 \mathrm{~mm}$. By the end of October all specimens without a winter ring ranged from 6 to $11 \mathrm{~mm}$. with an average size of $8.1 \mathrm{~mm}$.

The species therefore breeds in summer, probably about the end of June and July. The first distinct ring is the first winter ring. Growth is rapid and, since the shell is thin, there is not the same limitation to growth as might be expected in a species which secretes a heavy shell. Differences in conditions from year to year will therefore affect the rate of growth considerably ; for example, the first winter rings of the 1928 spat average considerably less than those of the 1929 spat (Table 6).

With regard to the other year-groups in the collections, the average sizes of the winter rings and of total lengths have been calculated for each collection (Table 6).

\section{TABLE 6 .}

Table Showing the Average Sizes in mm. of the Various Winter Rings and Total of $A$. ALBA in each Collection from Loch Striven IN 1931.

\begin{tabular}{|c|c|c|c|c|c|c|c|c|c|c|}
\hline & $\begin{array}{c}0 \\
\text { Ping }\end{array}$ & 1 & & & $\stackrel{2}{2}$ & & & & & \\
\hline & & & & & & & & $\mathrm{R}_{11}$ & igs. & \\
\hline & & $\begin{array}{l}\text { Winter } \\
\text { ring, } \\
1930-\end{array}$ & & $\begin{array}{l}\text { Winter } \\
\text { ring, } \\
1929-\end{array}$ & $\begin{array}{l}\text { Winter } \\
\text { ring, } \\
1930-\end{array}$ & $\therefore$ & $\begin{array}{l}\text { Winter } \\
\text { ring, } \\
\text { 1928- }\end{array}$ & $\begin{array}{l}\text { Winter } \\
\text { ring, } \\
1929-\end{array}$ & $\begin{array}{c}\text { Winter } \\
\text { ring, } \\
1930-\end{array}$ & \\
\hline Date. & Length. & 31. & Length. & 30. & 31. & Length. & 29. & 30. & 31. & Length. \\
\hline 23.2 .31 & $10 \cdot 0$ & $10 \cdot 4$ & $15 \cdot 0$ & $9 \cdot 2$ & $18 \cdot 0$ & $19 \cdot 6$ & . & • & . & • \\
\hline 19.6 .31 & • & $6 \cdot 7$ & $10 \cdot 8$ & $10 \cdot 3$ & $14 \cdot 6$ & $16 \cdot 3$ & $8 \cdot 4$ & $16 \cdot 2$ & $18 \cdot 3$ & $19 \cdot 2$ \\
\hline 20.8 .31 & $5 \cdot 6$ & $7 \cdot 0$ & $11 \cdot 5$ & $11 \cdot 0$ & $15 \cdot 6$ & $17 \cdot 4$ & $7 \cdot 0$ & $16 \cdot 1$ & $18 \cdot 6$ & $19 \cdot 6$ \\
\hline 29.10 .31 & $8 \cdot 1$ & $7 \cdot 8$ & $14 \cdot 8$ & $10 \cdot 8$ & $15 \cdot 9$ & $18 \cdot 1$ & $9 \cdot 0$ & $16 \cdot 7$ & $18 \cdot 7$ & $20 \cdot 0$ \\
\hline
\end{tabular}


In February the collection was a very small one and does not seem to have been quite representative of the station since no 1928 spat was found, and the means are all high in comparison with the figures for the rest of the collections. Disregarding these February figures, the average size in round figures at the end of each year would seem to have been approximately as follows (Table 7).

\section{TABLE 7.}

Table Showing the Approximate Size of the Various Spats in Loch Striven at the ENd of each Year of Growth.

$\begin{array}{ccccc}\text { Spat of } & \begin{array}{c}\text { At end of } \\ \text { First year. }\end{array} & \begin{array}{c}\text { At end of } \\ \text { Second Year. }\end{array} & \begin{array}{c}\text { At end of } \\ \text { Third Year. }\end{array} & \begin{array}{c}\text { At end of } \\ \text { Fourth Year. }\end{array} \\ 1931 & 8 \mathrm{~mm} . & . & . & . \\ 1930 & 8 \mathrm{~mm} . & 15 \mathrm{~mm} . & . & . \\ 1929 & 10 \cdot 7 \mathrm{~mm} . & 15.4 \mathrm{~mm} . & 18 \mathrm{~mm} . & . \\ 1928 & 8 \mathrm{~mm} . & 16.3 \mathrm{~mm} . & 18.5 \mathrm{~mm} . & 19 \cdot 6 \mathrm{~mm} .\end{array}$

The renewal of the spat in different years varies greatly (Table 8). During 1931 the survivors of the 1929 spat were the dominant year-group on the ground. The year 1929 seems, therefore, to have been a very favourable one for A. alba, for not only did the spat grow more than usual, judging from the size of the first winter ring (Table 7), but it survived in unusually large numbers (Table 8).

TABLE 8.

Table Showing the Numbers of each Year's Spat Surviving in the Collections taken in Loch Striven during 1931.

$\begin{array}{crccc}\text { Date. } & 1928 & 1929 & 1930 & 1931 \\ 23.2 .31 & \text { Spat. } & \text { Spat. } & \text { Spat. } & \text { Spat. } \\ 19.6 .31 & 5 & 17 & 1 & \text {. } \\ 20.8 .31 & 12 & 73 & 24 & . \\ 29.10 .31 & 16 & 43 & 13 & 64 \\ \text { Total } & 3 & 16 & 10 & 42 \\ & 36 & 149 & 48 & 106\end{array}$

The two collections taken by Mr. Moore in 1930 also show the same peculiarities, namely, the large size of the winter ring in the 1929 spat (Table 9), and the preponderance of that year-group in the collections (Table 10).

The preponderance of certain year-groups in the Abra population in Plymouth waters has been indicated by Ford (2, p. 544). The 1922 brood 
was one such group, and judging by its size at the end of successive years (Ford, 2, p. 543) its growth was much slower than that of Abra from Loch Striven.

\section{TABLE 9.}

Table Showing the Mean Sizes of the Various Winter Rings In $A$. ALBA taken at Stns. 10 and 11 on 1.9 .30 .

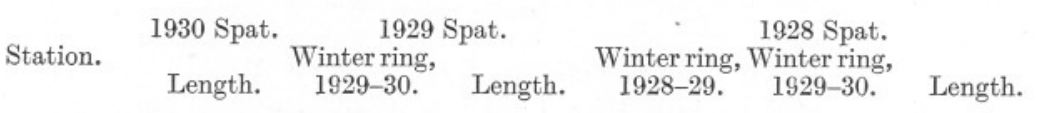

$10 \quad 11 \cdot 0 \mathrm{~mm} .12 \cdot 7 \mathrm{~mm} .16 \cdot 1 \mathrm{~mm} .8 \cdot 7 \mathrm{~mm}$. $15 \cdot 7 \mathrm{~mm}$. $19 \cdot 0 \mathrm{~mm}$.

11 ? $10 \cdot 7 \mathrm{~mm} .15 \cdot 5 \mathrm{~mm} \cdot 7 \cdot 2 \mathrm{~mm} .17 .2 \mathrm{~mm} .19 \cdot 3 \mathrm{~mm}$.

TABLE 10.

Table Showing the Numbers of Survivors of the Spat of Various

Years in the Collections from Stns. 10 and 11 on 1.9.30.

$\begin{array}{cccc}\text { Station. } & \text { Sp28 } & \text { 1929 } & 1930 \\ 10 & 3 & 99 & \text { Spat. } \\ 11 & 17 & 60 & \text { ? }\end{array}$

As in the case of the material collected in 1931 so in this 1930 material the spat of 1929 formed by far the largest part of the collections, and similarly its first (1929-30) winter ring was much larger than that of the 1928 spat.

It has already been shown how in the Clyde area both $C$. edule and $T$. tenuis grow fastest at some particular level. In this case it is not easy to draw conclusions, since too much stress must not be laid on the averages of the 1928 spat for Station 10 where only three specimens were taken.

Judging from the averages of the 1929 spat, $A$. alba seems to grow at a distinctly greater rate in the shallower water, especially in the first year when growth is greatest.

There is a fair range of size in both the winter ring and in the length of the 1929 spat, and the question arises whether there is any correlation between the two, e.g. is the rate of growth in the second year of life of spat which has grown poorly in the first year less than that of spat which has grown well? In Table 11 the range and average size of the first winter ring for the 1929 spat are tabulated against each $\mathrm{mm}$. in length of shell at the end of 1930. While some individuals which have grown slowly in their first year overtake by the end of the second year individuals which have grown well in their first year, on the average those individuals which have grown well in their first year tend to be larger at the end of the second year. It is noticeable, also, how growth in the second year at 
Station 11 (mid-loch) was greater than at Station 10 (loch head), thus reversing the positions during the first year.

TABLE 11.

Table Showing the Range and Average Size of the 1929-30 Winter Ring in the 1929 Spat for Individuals at Each mm. of Length IN the End of 1930 at StNs. 10 and 11.

$\begin{array}{ccccc}\begin{array}{c}\text { Length in } \\ \text { mm. at the } \\ \text { end of 1930. } \\ 19 \mathrm{~mm} .\end{array} & \begin{array}{c}\text { Average size } \\ 1929-30 \\ \text { winter ring. }\end{array} & \begin{array}{c}\text { Range in } \\ \text { size of } \\ \text { winter ring. }\end{array} & \begin{array}{c}\text { Station } 11 . \\ \text { Average size } \\ 1929-30 \\ \text { winter ring. }\end{array} & \begin{array}{c}\text { Range in } \\ \text { size of } \\ \text { winter ring. }\end{array} \\ 18,, & 14 \cdot 4 & 14-15 & . & . \\ 17,, & 13 \cdot 7 & 13-15 & 13 \cdot 0 & 12-15 \\ 16,, & 13 \cdot 8 & 11-15 & 12 \cdot 1 & 11-14 \\ 15,, & 12 \cdot 6 & 11-14 & 10 \cdot 7 & 8-12 \\ 14,, & 10 \cdot 4 & 11-13 & 11 \cdot 2 & 8-13 \\ 13,, & 11 \cdot 0 & 9-12 & 8 \cdot 2 & 8-12 \\ 12,, & 9 \cdot 3 & 10-12 & 8 \cdot 0 & 7-9 \\ & & 9-10 & . & .\end{array}$

The years 1926 and 1930 were years of specially abundant spat-fall in the Cumbrae area for C. edule (1926 only), T. tenuis, and T. fabula, but the conditions which favoured them do not seem to favour A. alba. There are no comparable figures for 1926, but 1929, not 1930, was a brood year for A. alba. If it is a general rule that the peak years for these species do not coincide it would be a matter of some economic importance for plaice grounds where A. alba, T. fabula, and Nucula nitida are the dominant forms. Such variations in the quantity of fish food in certain Danish areas brought about by the variations in the density of the constituent species have been traced by Blegvad (1).

\section{Loch Fyne. CARdum Edule.}

During the summer of 1931, and again in the autumn of that year, several of the sand-flats on Loch Fyne were visited. The most interesting of these was at the head of the Loch, a fairly extensive stretch of coarse sand over which a heavy flow of fresh water finds its way. The Cardium zone extends over the lower half of the beach and for some little distance, to about 1 fathom, beyond L.W.M. Compared with other cockle grounds visited, this one is displaced to seaward, the brackish conditions probably being responsible.

In August, 1931, a $\frac{1}{4}$ sq. m. cut was sieved and a large sample picked up at random by hand from each of two stations, one at L.W.M. and the other at a point 100 yards up the beach. Again in October similar collections were 
made, only on that date the tide was not quite so good and the October stations are therefore some little distance landward of the August ones. In addition some dredging was done, in about 1 fathom, to secure some of the large cockles which could be seen from the boat, and to determine the seaward limit of distribution.

When the intertidal collections were examined they were seen to be remarkable in that, with the exception of two old specimens from L.W.M., all belonged to the 1929 or 1930 spat, the former predominating. The few cockles secured from below L.W.M. were all very much older. That is to say above L.W.M. all the cockles had been killed off after the 1928 spat-fall but before that of 1929. Almost certainly this is to be accounted for by the specially hard winter of 1928-29. During February the frost was very severe. According to statements from local fishermen the area at the head of the loch was then frozen up to an unusual degree. Other species seem to have suffered as well. On such a ground one would expect to find Macoma baltica in quantity, especially in the upper levels, yet only a few old, many-ringed, and much eroded, specimens were found near L.W.M. It would appear, therefore, that only the Cardium population below L.W.M. and the old deeply buried Macoma escaped destruction by the frost.

There are several interesting points about this new cockle population. In the first place the continued absence at either station of any specimens older than the 1929 spat, such as occur below L.W.M., shows that there has been no migration. A similar conclusion was reached from a study of the sizes of the various annual rings for the cockle population on the Hunterston Sands.

The falling off in the rate of growth from the seaward to the landward area of the cockle ground, so well shown on the Hunterston beds, is very evident here also (Table 12).

TABLE 12.

Table Showing the Numbers of each Year's Spat, the Average Size of the Winter Rings, and Length of the Cockles in the Quantitative Samples from the Head of Loch Fyne.

\begin{tabular}{|c|c|c|c|c|c|}
\hline Date of & Station & & Number of & $\begin{array}{l}\text { Average size } \\
1930-31 \\
\text { winter ring }\end{array}$ & Average \\
\hline 13.8 .31 & L.W.M. $\frac{1}{4}$ sq. m. $\times 2$ & $\begin{array}{l}1929 \\
1930\end{array}$ & $\begin{array}{c}\text { specimens. } \\
21 \\
6\end{array}$ & $22 \cdot 6 \mathrm{~mm}$. & $\begin{array}{l}34.8 \mathrm{~mm} \text {. } \\
18.9 \mathrm{~mm} \text {. }\end{array}$ \\
\hline " & $\begin{array}{l}100 \text { yards up from } \\
\text { L.W.M. } \frac{1}{4} \text { sq. m. }\end{array}$ & $\begin{array}{l}1929 \\
1930 \\
1929\end{array}$ & $\begin{array}{r}10 \\
5 \\
14\end{array}$ & $\begin{array}{l}16.3 \mathrm{~mm} . \\
20 \cdot 2 \mathrm{~mm} .\end{array}$ & $\begin{array}{l}25.0 \mathrm{~mm} \text {. } \\
11.6 \mathrm{~mm} \text {. } \\
30.7 \mathrm{~mm} .\end{array}$ \\
\hline 28.10 .31 & L.W.M. $\frac{1}{4} \mathrm{sq} \cdot \mathrm{m} . \times 2$ & $\begin{array}{l}1930 \\
1931\end{array}$ & $\begin{array}{r}5 \\
12\end{array}$ & : & $\begin{array}{r}20.1 \mathrm{~mm} . \\
6.0 \mathrm{~mm} \text {. }\end{array}$ \\
\hline , & $\begin{array}{l}100 \text { yards up from } \\
\text { L.W.M. } \frac{1}{4} \text { sq. m. }\end{array}$ & $\begin{array}{l}1929 \\
1930 \\
1931\end{array}$ & $\begin{array}{r}31 \\
3 \\
0\end{array}$ & $\begin{array}{c}19.0 \mathrm{~mm} . \\
.\end{array}$ & $\begin{array}{c}26.0 \mathrm{~mm} \\
15.7 \mathrm{~mm} \\
\text {. }\end{array}$ \\
\hline
\end{tabular}


The shells from this beach are much eroded, especially those from the upper parts. The specimens collected in August were not much damaged, but those taken in October in the upper levels were so badly eroded as to be almost, or entirely, perforated in the upper half of the shell.

The range in size of the 1929 spat taken in October is 12 or $13 \mathrm{~mm}$., and it is of interest to trace the relationship between the length of the winter ring on any shell and the length of the shell itself. In Table 13 the average size of the winter rings of all specimens at each $\mathrm{mm}$. is given, and at both stations it is evident that there is a definite relationship. In general, those specimens which have grown best in their first year of life are the largest at the end of their second, and vice versa. There are, of course, individual cases where the leeway is made up.

\section{TABLE 13.}

Table Showing a Comparison of the Average Sizes of the Winter Rings for Individuals at each m. Size in October, 1931. Hand Samples.

\section{L.W.M. 13.8 .31}

$\begin{array}{ccc}\text { Number of } & \begin{array}{c}\text { Average } \\ \text { size of } \\ \text { specimens. } \\ \text { in mm. }\end{array} & \begin{array}{c}190-31 \\ \text { winter ring. }\end{array} \\ 1 & 36 & 27 \\ 1 & 35 & 25 \\ 5 & 33 & 24 \cdot 2 \\ 5 & 32 & 23 \cdot 8 \\ 27 & 31 & 22 \cdot 9 \\ 23 & 30 & 21 \cdot 7 \\ 17 & 29 & 21 \cdot 2 \\ 5 & 28 & 20 \cdot 0 \\ 6 & 27 & 21 \cdot 0 \\ 3 & 26 & 20 \cdot 0 \\ 1 & 25 & 18 \cdot 0 \\ 1 & 24 & 18 \cdot 0\end{array}$

100 yards up from L.W.M. Station

\begin{tabular}{|c|c|c|}
\hline & 13.8.31 & Average \\
\hline $\begin{array}{l}\text { Number of } \\
\text { specimens. }\end{array}$ & & $\begin{array}{c}\text { size of } \\
1930-31\end{array}$ \\
\hline specimens. & Length. & winter ring \\
\hline 1 & 33 & 20 \\
\hline 1 & 31 & 25 \\
\hline 6 & 30 & $23 \cdot 2$ \\
\hline 12 & 29 & $22 \cdot 1$ \\
\hline 16 & 28 & $21 \cdot 2$ \\
\hline 21 & 27 & $20 \cdot 2$ \\
\hline 12 & 26 & 19.2 \\
\hline 8 & 25 & 17.9 \\
\hline 7 & 24 & $17 \cdot 0$ \\
\hline 2 & 23 & 14.5 \\
\hline$\hat{1}$ & 21 & $11 \cdot 0$ \\
\hline
\end{tabular}

L.W.M. 28.10 .31

$\begin{array}{ccc}\text { Number of } & \text { Length } & \begin{array}{c}\text { Average } \\ \text { size of } \\ 1930-31 \\ \text { specimens. }\end{array} \\ \text { winter ring. } \\ 1 & 35 & 24 \\ 3 & 34 & 21 \\ 8 & 33 & 22 \cdot 1 \\ 16 & 32 & 21 \cdot 2 \\ 31 & 31 & 20 \cdot 0 \\ 32 & 30 & 19 \cdot 9 \\ 15 & 29 & 20 \cdot 2 \\ 10 & 28 & 18 \cdot 9 \\ 6 & 27 & 18 \cdot 8 \\ 5 & 26 & 19 \cdot 2\end{array}$

\begin{tabular}{|c|c|c|}
\hline \multicolumn{3}{|c|}{100 yards up from L.W.M. Station } \\
\hline & & $\begin{array}{c}\text { Average } \\
\text { size of }\end{array}$ \\
\hline $\begin{array}{l}\text { Number of } \\
\text { specimens. }\end{array}$ & Length. & $\begin{array}{c}1930-31 \\
\text { winter ring. }\end{array}$ \\
\hline 4 & 30 & $\begin{array}{l}\text { winter ring. } \\
22 \cdot 5\end{array}$ \\
\hline$\frac{4}{5}$ & $\begin{array}{l}20 \\
29\end{array}$ & $\begin{array}{l}22.5 \\
21.8\end{array}$ \\
\hline 26 & 28 & $20 \cdot 3$ \\
\hline 39 & 27 & 20.0 \\
\hline 40 & 26 & 19.0 \\
\hline 34 & 25 & 17.6 \\
\hline 26 & 24 & 16.8 \\
\hline 15 & 23 & 16.8 \\
\hline 8 & 22 & 17.5 \\
\hline 1 & 21 & 15 \\
\hline 1 & 20 & 13 \\
\hline 2 & 19 & $14 \cdot 5$ \\
\hline 3 & 17 & 13.7 \\
\hline
\end{tabular}


There is also the comparison between the weight of the shell and its length at the two positions on the beach to be considered (Table 14). This relationship has only been worked out for the August collections, the extent of the erosion in the October material making comparison impossible. For the August samples the graph of $\frac{\text { weight }}{\text { length }}$ (Fig. 3) is not a straight line, possibly in part due to the small number of specimens, but, taking the best line amongst the points, it is clear that at L.W.M. the shells are distinctly heavier, length for length, than those further up the beach.

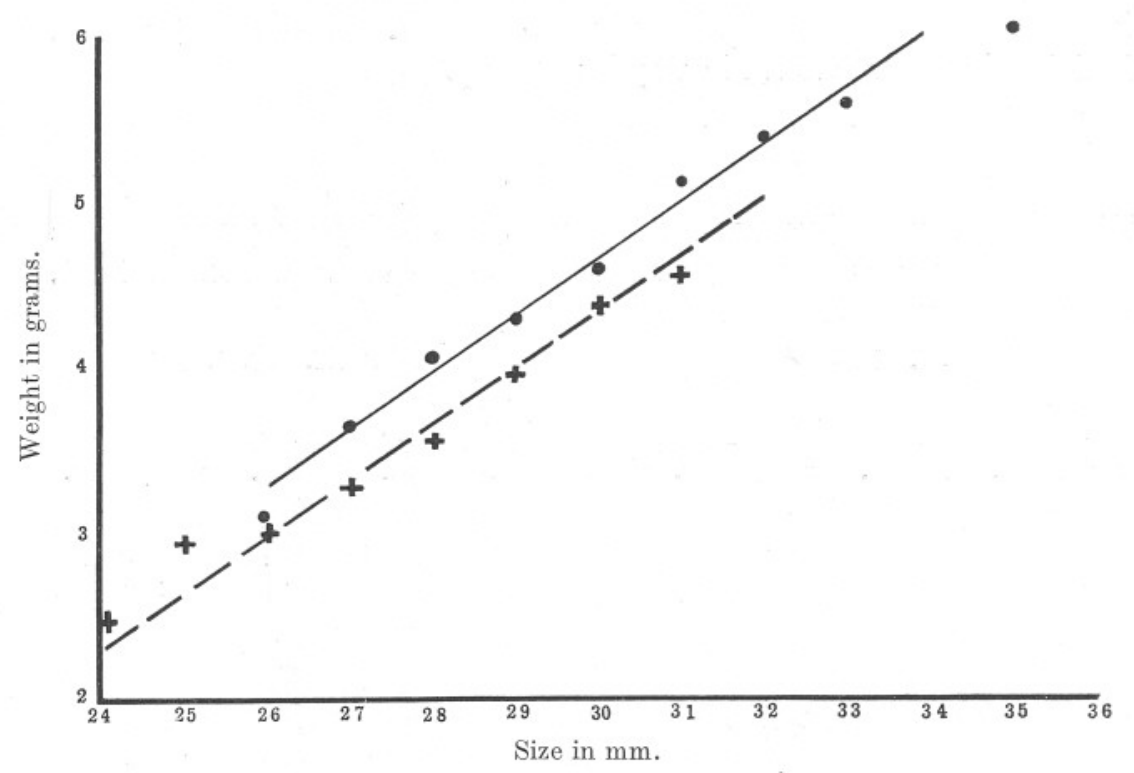

FIG. 3.- Showing the relation length to weight in Cardium edule shells from Loch Fyne Head. Dots represent the figures for the Station at L.W.M. ; Crosses represent the figures for the Station one hundred yards up the beach.

Thus Cardium edule not only grows faster at the seaward part of its range, but lays down a heavier shell, i.e. has more available lime. The other common shore form, Tellina tenuis, on the other hand, grows best at the landward part of its range provided the beach remains uniform in nature, e.g. Kames Bay or St. Andrews Sands. Where the Tellina ground overlaps the Cardium ground $T$. tenuis gets smaller before dying out, seemingly not thriving well on the type of ground occupied by Cardium. This difference between the two species can be accounted for by the difference in feeding habits. Cardium burrows in the sand with its short siphons projecting a little way above the surface and draws in a strong current of water from which it collects its food. The further up the beach, therefore, 
the longer it is exposed during ebb tide and the less time it has for feeding. Tellina, on the other hand, feeds on detritus. It has long siphons which are kept waving about, the inhalent one searching the bottom and picking up particles which can be seen travelling down the siphon. On a short even beach, therefore, even the higher levels for a short time provide a period of rich feeding for an animal of this kind.

TABLE 14.

Table Showing the Average Weight for each mm. Length in the Shells of Cardium from Loch Fyne.

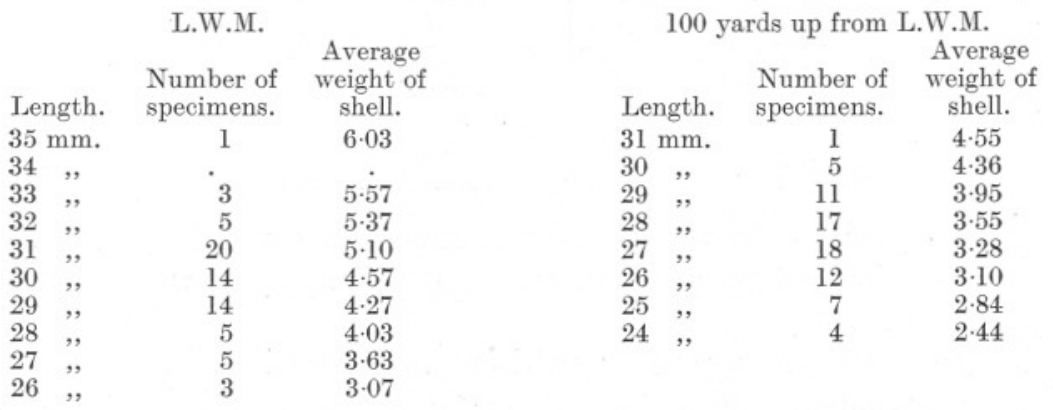

TABLE 15.

Table Showing the Age Composition of the Collections of Cardid M

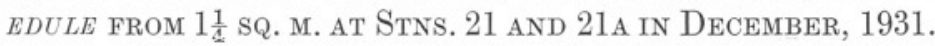

$\begin{array}{ccccccccc}\text { Station. } & 1924 . & 1925 . & 1926 . & 1927 . & 1928 . & 1929 . & 1930 . & 1931 . \\ 21 & . & 4 & 39 & 4 & 3 & 3 & 2 & 35 \\ 21 \mathrm{a} & 2 & . & 40 & . & . & 2 & 2 & 8\end{array}$

\section{Hunterston Sands.}

The rate of growth of the cockle and the differences in size at various levels on these sands were investigated during 1929-30, so during 1931 only a few samples were taken to confirm certain points, chiefly the agecomposition of the Cardium population.

The 1926 spat was for several years the dominant year-group in the collections of Cardium and Tellina from Hunterston and Kames Bay respectively, but during 1930 the 1926 Tellina group largely died out and was replaced by the new 1930 spat. To test if parallel events had taken place on the Cardium grounds certain of the stations on Hunterston were re-examined in December, 1931 (Appendix, p. 68). In this case, however, there had been no replacement, the 1926 spat still predominating (Table 15), most of the other year-groups being represented by only one or two specimens. 
The growth of the cockle was previously shown to be greatest at the seaward part of its range, and this is confirmed by a comparison of the mean sizes of the various winter rings of the 1926 spat at the two stations (Table 16). The divergence of the means at the two stations increased with each year.

TABLE 16.

Table Showing the Average Size of the Annual Rings on the 1926 Spat in December, 1931.

$\begin{array}{cccccc}\text { Station. } & \begin{array}{c}\text { Winter ring } \\ 1927-28 .\end{array} & \begin{array}{c}\text { Winter ring } \\ 1928-29 .\end{array} & \begin{array}{c}\text { Winter ring } \\ 1929-30 .\end{array} & \begin{array}{c}\text { Winter ring } \\ 1930-31 .\end{array} & \text { Length. } \\ 21 & 21 \cdot 7 & 30 \cdot 1 & 34 \cdot 3 & 36 \cdot 8 & 39 \cdot 2 \\ 21 \text { la } & 17 \cdot 7 & 23 \cdot 2 & 25 \cdot 6 & 27 \cdot 6 & 28 \cdot 8\end{array}$

\section{Renewal of a Lamellibranch Population.}

With regard to the renewal of a Lamellibranch population on any ground an interesting question arises in the light of the foregoing observations.

It has already been pointed out how, in Kames Bay in September, 1926, the population of $T$. tenuis consisted almost entirely of spat, and how in the autumn of 1930 spat again predominated after the adults had largely disappeared.

The same would seem to have been true of Cardium on the Hunterston Sands in 1926-much spat with few adults, and in subsequent years little spat. Further, in Loch Fyne, the ground was repopulated by Cardium in 1929, a year which, judging from the conditions at Hunterston, did not seem to be an outstanding brood year for Cardium.

The question therefore is : must the adult population almost die out before the ground can be repopulated? if so, is there sufficient spat produced every year to repopulate the ground? or is there a cycle with years of special spat production?

It would seem, from the results just quoted, that the clearing of the ground of adults, for example, as a result of high mortality after spawning or after unusual frost, is the important factor.

There is doubtless a high survival of spat in certain years which affects the rate of repopulation. At Loch Fyne Head, for example, it is not possible to say what difference in density of population there might have been had the frost come in another year. Simply from a study of the agecomposition of a collection, without reference to the actual density of population, a poor spat on fallow ground would give the impression of a year of high spat survival. 


\section{SUMMARY.}

The paper deals with four species from the Clyde Area, namely : Tellina tenuis, Tellina fabula, Abra alba, and Cardium edule.

T. TENUIS.

1. The growth at one station below L.W.M. in Kames Bay is considered. This is slower than in any other part of its vertical range.

2. Heavy spat-falls were recorded in 1926 and in 1930, but, in both cases, the spat grew slowly and died off quickly at the stations below L.W.M.

3. The general rate of growth for the species from its upper to its lower limit of distribution in Kames Bay is tabulated.

\section{T. FABULA.}

1. An investigation was made at one station in $1 \frac{1}{2}$ fathom in Kames Bay during 1931.

2. A length of about $4 \mathrm{~mm}$. is attained at the end of the first year; $8 \mathrm{~mm}$. at the end of the second year; and $10 \mathrm{~mm}$. at the end of its third year.

3. The years 1926 and 1930 seem to have been years of exceptional spat-survival for this species as well as for T.tenuis.

\section{CARDium Edule.}

1. The species was studied in Loch Fyne and on the Hunterston Sands.

2. On the shore at the head of Loch Fyne all Cardium above L.W.M. were killed off by the severe winter of 1928-29. Most of the present Cardium population is derived from the 1929 spat.

3. The rate of growth is greater at L.W.M. than further up the beach.

4. Specimens which have grown slowly in their first year tend to lag behind those which have grown well.

5. The graph $\frac{\text { weight of shell }}{\text { length of shell }}$ is given. Shells from higher levels are, length for length, distinctly lighter than those from lower levels.

6. Two of the stations on the Hunterston Sands were re-examined in the autumn of 1931 and the 1926 spat still found to be the dominant year-group. 
Abra ALBA.

1. Collections from two stations, both in Loch Striven, are discussed.

2. The 1929 spat was the dominant year-group and seems to have grown specially well in its first year.

3 . The rate of growth is fast, especially in the first year, and is subject to considerable variation from year to year.

4. The average age for the animal in this area would seem to be about 3 or 4 years.

\section{LITERATURE CITED.}

1. Blegvad, H. Continued Studies on the Quantity of Fish Food in the Sea Bottom. Rept. Danish Biol. Station, Vol. XXXI, 1925, p. 27.

2. Ford, E. On the Growth of some Lamellibranchs in Relation to the Food-supply of Fishes. Journ. Mar. Biol. Assoc., N.S., Vol. XIII, $1923-25$, p. 531.

3. Stephen, A. C. Notes on the Biology of certain Lamellibranchs on the Scottish Coast. Journ. Mar. Biol. Assoc., N.S., Vol. XVII, No. 2, p. 277, 1931.

\section{APPENDIX.}

Positions of the stations at which the various species were collected.

Abra Alba.

Stn. 10. Loch Striven Head. Mud.

Stn. 11. Loch Striven. Mid-loch off Inverchoalain. Mud.

Tellina tenuis.

Kames Bay. Millport. Sand. $1 \frac{1}{2} \mathrm{fms}$.

Tellina fabula.

Kames Bay. Millport. Sand. $1 \frac{1}{2} \mathrm{fms}$.

\section{Cardium edule.}

Loch Fyne. Intertidal stretch at the head of the loch.

Hunterston Sands.

Stn. 21. South-west end of the sands about half-tide, in the middle of the cockle bed.

Stn. 21a. About 100 yards up the beach from Stn. 21. 